Asian J. Med. Biol. Res. 2018, 4 (4), 362-371; doi: 10.3329/ajmbr.v4i4.40108

\author{
Asian Journal of \\ Medical and Biological Research \\ ISSN 2411-4472 (Print) 2412-5571 (Online) \\ www.ebupress.com/journal/ajmbr
}

\title{
Article \\ Study and quantitative analysis of wild vegetable floral diversity available in Barisal district, Bangladesh
}

Uzzal Hossain* and Ashikur Rahman

Department of Botany, University of Barisal, Barisal-8200, Bangladesh

*Corresponding author: Md. Uzzal Hossain, Department of Botany, University of Barisal, Barisal-8200, Bangladesh. Phone: +8801737837649; E-mail: Uzzal.bu.bot@gmail.com

Received: 26 November 2018/Accepted: 19 December 2018/ Published: 30 December 2018

\begin{abstract}
In Barisal district of Bangladesh, a market survey was carried out to document the local wild vegetables floral diversity consumed by rural people and also inhabitants of metropolitan city, compare the botanical and agronomical characteristics. A total of 100 wild vegetable species belonging to 46 families have been documented from Barisal district. Among 100 wild vegetables $65 \%$ species are ethnomedicinally important and $52 \%$ are available in the all the year round. Among the species $75 \%$ hurb, $19 \%$ climber, $4 \%$ shrub and $2 \%$ trees. Leaf is most frequently used plant parts consumed and fallow land is the important source of these wild vegetables. Among 46 plant families Amaranthaceae and Araceae were recorded as most prominent. Market potentiality proportionally correlated with taste, ethnomedicinal value and use frequency but inversely correlated with distribution area, community status. Wild vegetable floral species having ethnomedicinal value, better in taste are rare and distributed into certain remote areas because frequent consumption result fast reduction from hand reach sources. Findings of this study could provide baseline data to conserve these wild vegetables, further agronomical investigation to domesticate them for sustainable use.
\end{abstract}

Keywords: wild vegetables; floral diversity; ethnomedicinal; quantitative analysis; Barisal

\begin{abstract}
1. Introduction
Bangladesh is blessed with wide range of wild edible floral species used as vegetable that include herbs, shrubs, and trees because of wide range of climatic condition in a year. Barisal district of Bangladesh is so much rich in wild vegetable diversity as a metropolitan city. Because of pollution from growing population, industrialization, global warming and urbanization, decreasing arable and fallow land resulting shortage in vegetables production in remaining metropolitan areas. Moreover, day by day industrialization forcing human being to search for organic vegetables which tend to green farming in case of cultivated vegetable. But it is difficult to provide sufficient amount of cultivated vegetable for its total population especially organic vegetables. Wild edible vegetables are only the alternative way to meet up the demand of green vegetable. In spite of availability of cultivated vegetables in Barisal, its local people utilizes a variety of wild plant species as green vegetables having long tradition for usage in culinary purposes. However, often these wild edible vegetables are dietary supplement and nutritionally superior to the cultivated ones too (Grivetti et al., 2000; Cook et al., 2000; Rashid, 1999; Freiberger et al., 1998). Moreover, wild food plants are inexpensive, locally available and have a great socioeconomic significance (Baro et al., 2015). But the contribution of wild edible vegetable in nutrition security has not yet been given sufficient attention in Bangladesh.

Once consumption of wild vegetable was limited among rural people because of lack of proper documentation, restriction in exchange of wild vegetable knowledge from one region to another and lack of public awareness. But in last one and half decades several survey and documentation has been made on traditional knowledge of wild vegetables for publication and exchange of this knowledge resulting previous situation reversed. The demand of wild vegetables are increasing day by day may be due to having ethnomedicinal value ((Brand-Miller
\end{abstract}


et al., 1998), availability in all seasons, stress tolerant (Cook et al., 2000) and alternative source of vegetables especially organic vegetables. A large number of wild vegetables, medicinal plants and other wild resource species are reported to be disappearing rapidly in Bangladesh due to reduction of natural habitats (FAO, 1984) by deforestation, agricultural land expansion, river erosion, over population. Information on the diversity, composition of wild vegetable flora and their structure is not well documented. Sajib et al. (2012), Majumdar et al. (2018), Abdullah et al. (2007, 2017), Rahman et al. (2015), Sarker et al. (2009), Khatun et al. (2013), Rashid et al. (1996) tried to make survey on wild vegetables in different parts of Bangladesh. But the findings of the aforementioned authors are limited and sporadic. However, for well documentation of knowledge on wild vegetables in many unexplored areas and communities remaining in the country is prerequisite to be revealed. In this point no study has been carried out on exploration, documentation and quantitative analyses of wild vegetables used by local people of Barisal district, Bangladesh. Therefore, the objectives of the present study include: to exploration of wild vegetable available in Barisal region, to identify the frequently consumed and marketed wild vegetable species by the local people, to document their traditional uses, to determine the consensus of medicinal uses, and finally to make a basis for future cultivation, conservation.

\section{Materials and Methods}

\subsection{Study area}

Barisal is under AEZ-13 named Ganges tidal floodplain and one of the riverine southern districts of Bangladesh lying between $22^{\circ} 27^{\prime}$ and $22^{\circ} 52^{\prime} \mathrm{N}$ and $90^{\circ} 01^{\prime}$ and $90^{\circ} 43^{\prime} \mathrm{E}$. The greater part of this region has smooth relief having large areas of salinity, with medium to high organic matter containing non-calcareous grey floodplain soils (FAO, 1997). This district is demarked by Madaripur, Shariatpur and Chandpur districts on the north, Patuakhali, Barguna and Jhalkhati districts on the south, Bhola and Lakshmipur districts on the east, and Pirojpur, Jhalkhati and Gopalganj districts on the west. This district consists of 10 upazillas, viz., Agailjhara, Babuganj, Bakerganj, Banaripara, Barisal Sadar, Gaurnadi, Hizla, Mehendiganj, Muladi and Wazirpur (Figure 1). Roadsides, fallow land, banks of rivers and all homesteads are usually covered by dense floral variety of both wild and cultivated species of plants resulting biodiversity enrich as industrialization, urbanization less affects this metropolitan city. Local people from periphery of metropolitan area come to city markets to sell wild vegetables collected by them for livelihood.

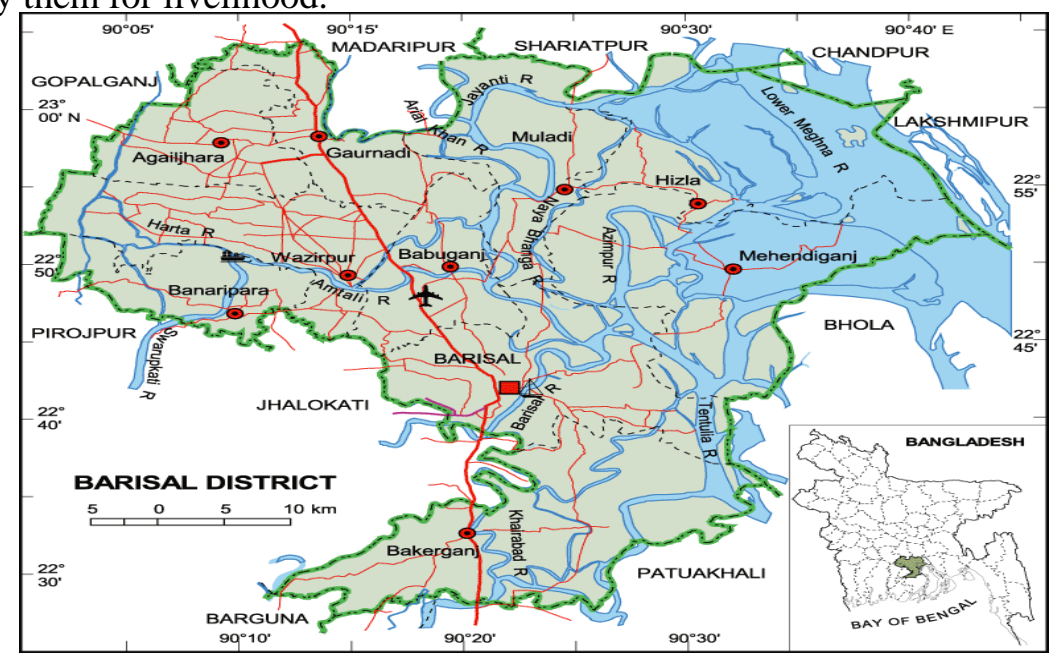

Figure 1. Study area.

\subsection{Vegetable samples and data collection}

From October 2017 to September 2018, twice in a season wild vegetables specimen, agronomical and botanical data associated with collected specimen were collected from the study area during periodical market surveys covering all the year round. The information related to wild vegetables obtained through local market survey and includes all higher plants and Pteridophytes, occurring wild in all available habitats. A total of 62 informants of all aged including both male and female of wild vegetables collectors and sellers have been interviewed from 26 local markets and public gathering places in Barisal district (Figure 2). During the survey information related to edibility of vegetables, parts used, taste status, market potentiality, availability status, harvesting season, ethnomedicinal value, sources of harvesting were recorded. The collected data were placed on to computer to prepare a database through Microsoft Excel. Specimens of each wild vegetables were 
collected, botanically analyzed and identified by experts using standard literature (Ahmed et al., 2007-2009). Voucher specimens were prepared using standard protocol (Hyland, 1972; Alexiades, 1996) and preserved at the Department of Botany, University of Barisal. The wild vegetables were enumerated alphabetically with their botanical name.

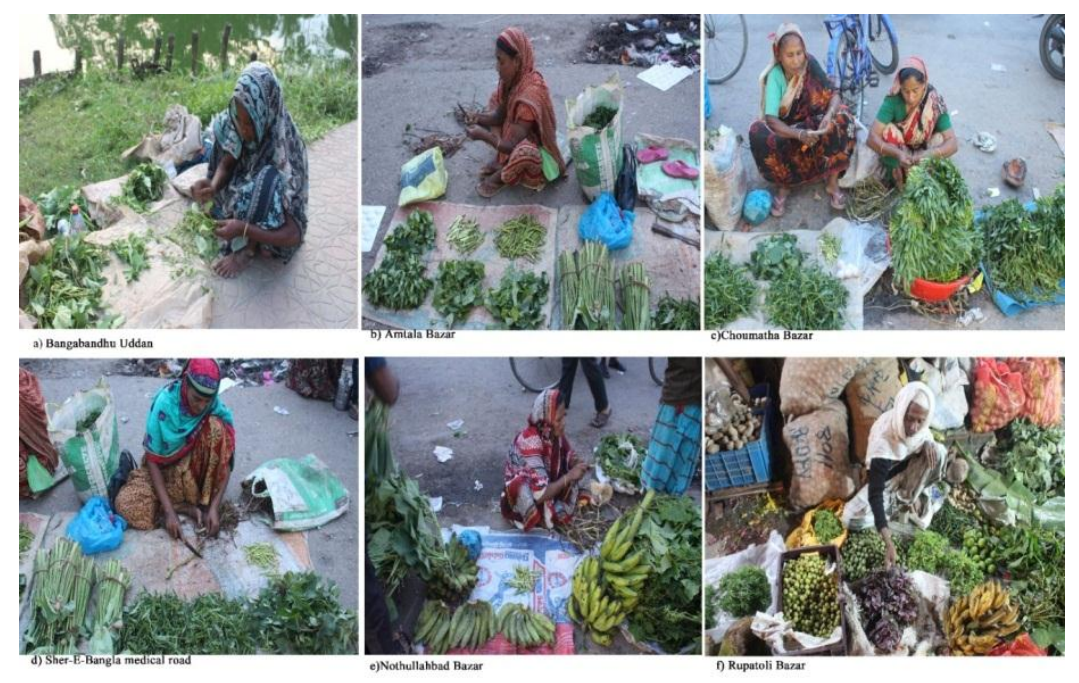

Figure 2. Marketing of wild vegetables in different locations of Barisal metropolitan city.

\section{Results and Discussion}

\subsection{Demographic characteristics of informants}

During survey just before the selling started face to face interviews were conducted for collection of detail demographic characteristics of informants. Among the informants age groups 46-60 was highly contributed (53.22\%) compared to other groups (Table 1). This may be due to older people being experienced and get interested to sale wild vegetables suggesting that old people are aware of knowledge of uses and values of wild vegetables but young generation are not expert and not interested. Philips and Gentry (1993) showed that wild edible plant knowledge is gained early in life and increases only slowly with age. Bista (2004), Ladio et al. (2004) also found that the younger generation is not interested in such traditional ways as a result of acculturation. The small proportion of young generation documented in this survey were as helper of parents, some were due to lack of capital, some get engaged as family tradition, some were for livelihood, some were for more profit compared to sale cultivated vegetable, some were as part time income in leisure period. Female informant had higher contribution (69.35\%) compared to male (Table 1). This result suggest that women are enrich in wild vegetables knowledge than men. Collection of homestead plant parts for cooking at different times of the year, sharing of kitchen knowledge among female from their early life may be reasons for this. Shava (2005) reported that women have more knowledge of vegetable compared to men due to division of domestic chores, while men may be more versed with knowledge of indigenous fruits and edible roots. In the point of education maximum informant were illiterate (54.83\%) including both male and female (Table 1). This result indicates that young generation getting modern education but losing the knowledge of wild vegetables. As a result reluctance will be observed in case of wild vegetables consumption and marketing in future.

Table 1. Demographic profile of the informants included during survey.

\begin{tabular}{llll}
\hline Demographic parameter & Demographic features & Number of people & Percentage (\%) \\
\hline Age & $15-30$ & 12 & $19.35 \%$ \\
& $31-45$ & 17 & $27.42 \%$ \\
\multirow{3}{*}{ Gender } & $46-60^{+}$ & 33 & $53.22 \%$ \\
& Female & 43 & $69.35 \%$ \\
Education & Male & 19 & $30.65 \%$ \\
& Able to read and write & 9 & $14.52 \%$ \\
& Elementary school & 19 & $30.65 \%$ \\
\hline
\end{tabular}




\subsection{Diversity of wild vegetable-Habit, habitat, and parts used}

This study explored the rich floral diversity of wild vegetables and documented a total of 100 wild vegetables species belonging to 76 genera and 46 families of 39 angiospermic and 7 pteridophytic from the market survey (Table 2 and Table 3). This result indicates that southern part especially Barisal district of Bangladesh enjoy so rich wild floral diversity due to its diverged climatic condition resulting local people dependent upon its natural resources for any kind of wild plants needed for traditional purposes. With regard to family Amaranthaceae $(11 \%)$ is highest contributed family in terms of number of species followed by Araceae $(10 \%)$, , Asteraceae (6\%), Euphorbiaceae, Nymphaeaceae (5\%), Cucurbitaceae, Convolvulaceae, Lamiaceae, Apiaceae (each 4\%), Dioscoriaceae, Fabaceae, Solanaceae (each 3\%), Athyriaceae, Marsileaceae, Nyctaginaceae, Scrophulariaceae (each $2 \%$ ) and remaining others family contributed $1 \%$ resulting total contribution $30 \%$ (Table 3). Sajib et al. (2012), Mojumdar et al. (2018), also found that Amaranthaceae, Araceae, Asteraceae, Euphorbiaceae, Convolvulaceae, Cucurbitaceae frequently used plant families in case of Sandwip Island, Chittagong and Rajshahi district of Bangladesh respectively. In the study the frequently reported species were herb (75\%), followed by climber (19\%), shrubs (4\%), trees (2\%) (Figure 3). Abdullah et al. (2007), Sajib et al. (2012), Mojumdar et al. (2018) also found herb is the most dominant life form of wild vegetable in the districts Mymensingh, Chittagong and Rajshahi respectively. Harvesting seasons of $48 \%$ wild vegetable floras is seasonal consisting of winter, summer, monsoon and remaining $52 \%$ are available in the all the year round (Figure 4). On the contrary winter is the most notable season of cultivated vegetables availability. Sajib et al. (2012), Abdullah et al. (2017) found that monsoon, winter season has high contribution in case of wild vegetables harvesting in Sandwip Island, Chittagong and Rangamati district of Bangladesh respectively. This variation is may be due to variation in climatic condition, vegetation diversity. Leaves are the dominant with $60 \%$ contribution followed by fruit $10.4 \%$, rhizome $6.1 \%$, petiole $7.8 \%$, stem $2.6 \%$, aerial portion $5.2 \%$, seed, stolon and bulbil, (each 1.7\%) root, flower and shoot (each 0.9\%), in the context of parts used (Figure 5). Sajib et al. (2012), Mojumdar et al. (2018), Abdullah et al. (2007, 2017) also found that leaf is the dominantly consumed plant parts during their survey in Sandwip Isalnd, Chittagong, Rajshahi, Mymensingh and Rangamati district of Bangladesh respectively. Following features of leaf as vegetative organ available at any season, mostly active portion for bioactive compound, easily harvestable may be responsible for leaf as dominant among parts used. All these plants were collected from wild habitat and highest number of wild vegetables were collected from fallow land $38 \%$, followed by riverside $27 \%$, bushes $22 \%$, Roadsides $11 \%$, and crop fields $2 \%$ of the total species (Figure 6). Sajib et al. (2012) found the maximum contribution of fallow land as source of wild vegetable in Sandwip Island, Chittagong, Bangladesh. So fallow land are important source of wild vegetables available in all the year round in Bangladesh. So it is an important source for daily nutrition index. So conservation of fallow land is highly recommended to meet up the daily vegetable demand especially wild vegetables.

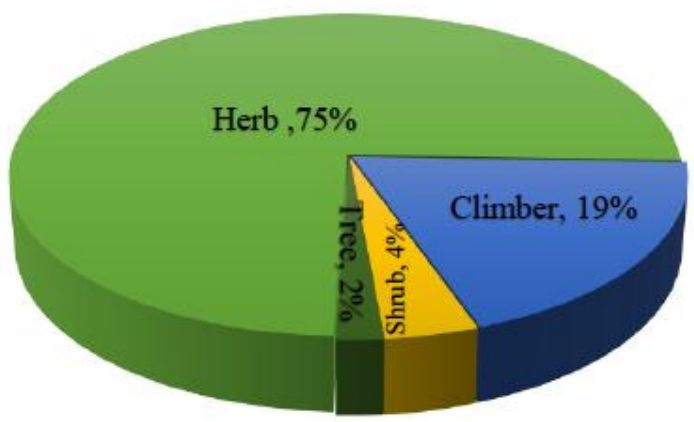

Figure 3. Comparative contribution of each plant habit.

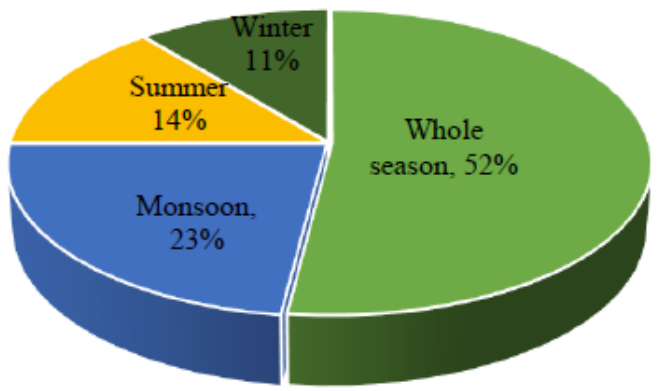

Figure 4. Comparative study on seasional availibility. 


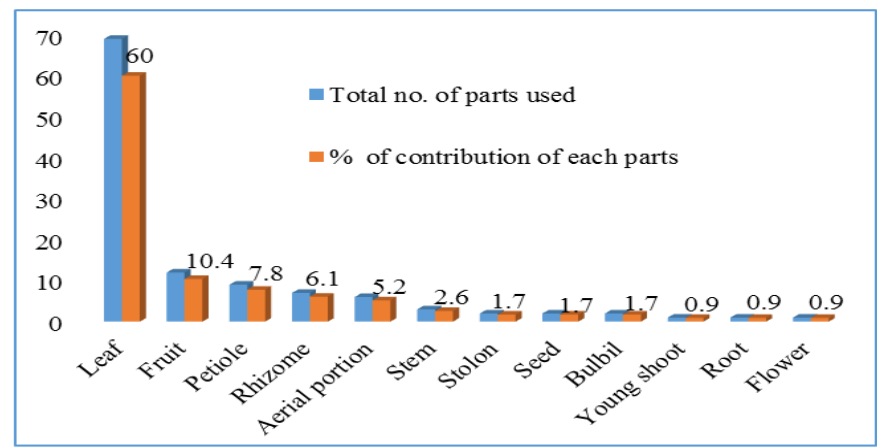

Figure 5. Number and percentage of each parts used.

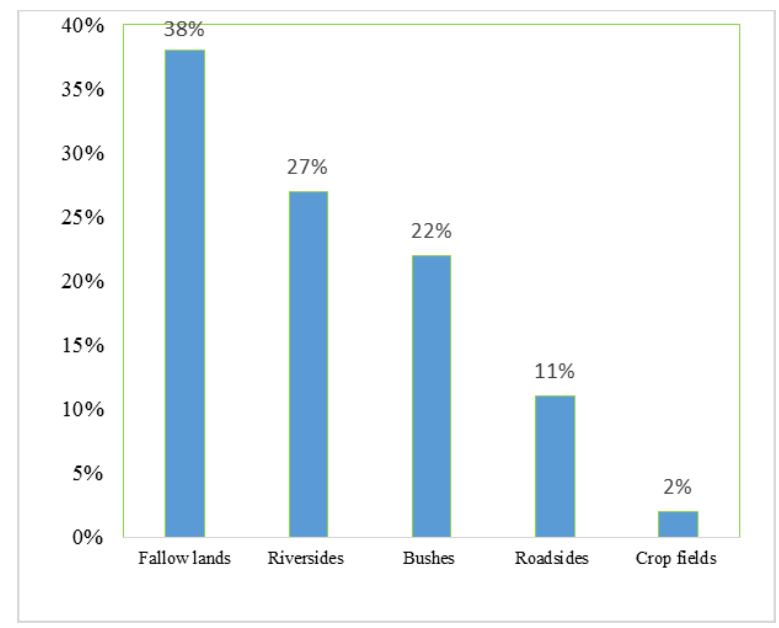

Figure 6. Comparative contribution of wild vegetables sources.

3.3. Diversity of evaluation criteria- Taste, market potential and ethnomedicinal value, distribution, community status and use frequency

Taste of 100 wild vegetable species documented from survey is classified into different categories with regard to various parameters. Among these categories taste of $54 \%$ wild vegetable is mostly preferred followed by commonly preferred (22\%), preferred but not common (13\%) and occasionally used (11\%) with regard to taste. In the view of use frequency $51 \%$ are widely used, followed by commonly used (21\%), occasionally used (16 $\%)$ and rare used (12\%) (Table 4). Wild vegetables that are in occasional and rare category with respect taste and use frequency respectively are bitter in taste and mostly used due to ethnomedicinial value. Ethnomedicinal contribution of 65 species are known and remaining 35 species are unknown (Table 4). Mercy et al. (2016), Mojumdar et al. (2018), Abdullah et al. (2007, 2017) also found that maximum of wild vegetables have ethnomedicinal, dietary and health benefits. Most of the wild vegetable (43\%) are distributed in the most of the region whereas $24 \%$ are found in certain regions and $29 \%$ are in remote regions of study area. In point of community status $33 \%$ are abundant followed by $25 \%$ common and $42 \%$ rare (Table 4). Mojumdar et al. (2018) also found that maximum of wild vegetables are in rare category. Maximum of the wild vegetables groups that found in remote regions and rare with regard to distribution area and community status respectively are ethnomedicinally important. These findings collectively suggest that ethnomedicinally important wild vegetables are in critical situation in ecosystem. This may be due to over consumption, habitats disturbance by human and cattle, removal as weeds during tilling, reduction in habitat for over population growth. Market potentiality proportionately correlated with taste, ethnomedicinal value and use frequency but inversely correlated with distribution area, community status (Table 4). 
Table 2. List of wild vegetable recorded from market survey.

\begin{tabular}{|c|c|c|c|c|c|c|c|c|}
\hline & Local name & Scientific name & Family & Habit & Parts used & Availability & Habitat & Life form \\
\hline 1. & Mukta jhuri & Acalypha indica & Euphorbiaceae & Herb & Leaf & abundant & Fallow land & Annual \\
\hline 2. & Boch & Achorus calamus & Acoraceae & Herb & Stem & common & Bush & Perennial \\
\hline 3. & Apangshak & Achyranthes aspera & Amaranthaceae & Herb & Leaf & common & Fallow land & Perennial \\
\hline 4. & Apang (Lal) & Aerva sanguinolenta & Amranthaceae & Herb & Leaf & Common & Fallow land & Perennial \\
\hline 5. & Mankachu & Alocasia macrorrhiza & Araceae & Herb & Stem, Petiole & Common & Riverside & Perennial \\
\hline 6. & Malanchashak* & Alternanthera philoxeroides & Amaranthaceae & Herb & Leaf & Rare & Fallow land & Perennial \\
\hline 7. & Sanchishak & Alternanthera sessilis & Amaranthaceae & Herb & Leaf & Rare & Fallow land & Perennial \\
\hline 8. & Knoteshak* & Amaranthus blitum & Amaranthaceae & Herb & Leaf & abundant & Fallow land & Perennial \\
\hline 9. & Knoteshak* & Amaranthus dubius & Amaranthaceae & Herb & Leaf & abundant & Fallow land & Perennial \\
\hline 10. & Knoteshak* & Amaranthus lividus & Amaranthaceae & Herb & Leaf & abundant & Fallow land & Perennial \\
\hline 11. & Bondatashak & Amaranthus oleraccus & Amaranthaceae & Herb & Leaf & abundant & Fallow land & Perennial \\
\hline 12. & Katanotey & Amaranthus spinosus & Amaranthaceae & Herb & Leaf & abundant & Fallow land & Perennial \\
\hline 13. & Knoteshak & Amaranthus viridis & Amaranthaceae & Herb & Leaf & abundant & Fallow land & Perennial \\
\hline 14. & Jongli ool & Amorphophallus bulbifer & Araceae & Herb & Petiole, Stem, Rhizome & Common & Bush & Annual \\
\hline 15. & Dhekiashak & Angiopteris evecta & Angiopteridaceae & Herb & Leaf & Common & Bush & Perennial \\
\hline 16. & Shotomuli & Asparagus racemosus & Liliaceae & Climber & Aerial & Rare & Riverside & Perennial \\
\hline 17. & Bramhishak & Bacopa monniera & Scrophulariaceae & Herb & Leaf & Rare & Roadside & Annual \\
\hline 18. & Bansh* & Bambusa longispiculta & Poaceae & Shrub & Young Shoot & Common & Bush & Perennial \\
\hline 19. & Dhekiashak (boro) & Blechnum orientale & Blechnaceae & Herb & Leaf & Common & Bush & Perennial \\
\hline 20. & Purnonapa & Boerhavia diffusa & Nyctaginaceae & Herb & Leaf & Rare & Fallow land & Perennial \\
\hline 21. & Moushim * & Canavalia gladiata & Fabaceae & Climber & Fruit & Common & Bush & Annual \\
\hline 22. & Phuti & Cardiospermum halicacabum & Sapindaceae & Herb & Leaf & Common & Fallow land & Annual \\
\hline 23. & Sonalu & Cassia fistula & Caesalpiniaceae & Tree & Flower & Common & Roadside & Perennial \\
\hline 24. & Morogjhutishak & Celosia cristata & Amaranthaceae & Herb & Leaf & Common & Roadside & Annual \\
\hline 25. & Thankuni & Centella asiatica & Apiaceae & Herb & Aerial portion & abundant & Fallow land & Perennial \\
\hline 26. & Panidhekia & Ceratopteris pteridiodes & Parkeriaceae & Herb & Leaf & Common & Riverside & Perennial \\
\hline 27. & Batuashak* & Chenopodium album & Chenopodiaceae & Herb & Leaf & Rare & Crop field & Annual \\
\hline 28. & Haraslata & Cissus quadrangularis & Vitaceae & Herb & Aerial portion & Rare & Fallow land & Perennial \\
\hline 29. & Aporajita & Clitoria ternatea & Fabaceae & Climber & Leaf & Common & Roadside & Annual \\
\hline 30. & Telakucha & Coccinea cordifolia & Cucurbitaceae & Climber & Leaf & abundant & Bush & Perennial \\
\hline 31. & Kachu* & Colocasia esculenta & Araceae & Herb & Aerial portion & abundant & Riverside & Perennial \\
\hline 32. & Kachu(boro)* & Colocasia gigantea & Araceae & Herb & Aerial portion & abundant & Fallow land & Perennial \\
\hline 33. & Kanchirashak* & Commelina benghalensis & Commelinaceae & Herb & Leaf & Rare & Fallow land & Perennial \\
\hline 34. & Bagi pat & Corchorus capsularis & Tiliaceae & Herb & Leaf & Common & Fallow land & Annual \\
\hline 35. & Metey alu* & Dioscorea alata & Dioscoriaceae & Climber & Leaf, Rhizome, Bulbil & Common & Bush & Annual \\
\hline 36. & Gasalu* & Dioscorea bulbifera & Dioscoriaceae & Climber & Leaf, Rhizome, Bulbil & Common & Bush & Annual \\
\hline 37. & Kataalu & Dioscorea pentaphylla & Dioscoriaceae & Climber & Rhizome & Common & Bush & Annual \\
\hline 38. & Dhekiashak* & Diplazium esculentum & Athyriaceae & Herb & Leaf & abundant & Riverside & Perennial \\
\hline 39. & Dekhiashak * & Diplazium polypodioides & Athyriaceae & Herb & Leaf & abundant & Roadside & Perennial \\
\hline 40. & Bhirangrazshak & Eclipta alba & Asteraceae & Herb & Leaf & abundant & Fallow land & Annual \\
\hline 41. & Helenchashak & Enhydra fluctuans & Asteraceae & Herb & Leaf & abundant & Riverside & Annual \\
\hline 42. & Belatidhonia & Eryngium foetidum & Apiaceae & Herb & Leaf & abundant & Fallow land & Perennial \\
\hline
\end{tabular}




\begin{tabular}{|c|c|c|c|c|c|c|c|c|}
\hline & Local name & Scientific name & Family & Habit & Parts used & Availability & Habitat & Life form \\
\hline 43. & Dudhia (Boro) & Euphorbia hirta & Euphorbiaceae & Herb & Leaf & abundant & Roadside & Annual \\
\hline 44. & Dudhia (Soto)* & Euphorbia orbiculata & Euphorbiaceae & Herb & Leaf & abundant & Roadside & Annual \\
\hline 45. & Makhna & Euryale ferox & Nymphaeaceae & Herb & Fruit & Common & Riverside & Annual \\
\hline 46. & Jogdumur & Ficus racemosa & Moraceae & Tree & Fruit & Common & Bush & Perennial \\
\hline 47. & Khirmoishak* & Hibiscus sabdariffa & Malvaceae & Shrub & Leaf & abundant & Fallow land & Perennial \\
\hline 48. & Gimashak & Hydrocotyle rotundifolia & Apiaceae & Climber & Leaf & Common & Fallow land & Annual \\
\hline 49. & Dudkalmi* & Ipomoea alba & Convolvulaceae & Climber & Leaf & abundant & Riverside & Perennial \\
\hline 50. & Kalmishak* & Ipomoea aquatica & Convolvulaceae & Climber & Leaf & abundant & Riverside & Perennial \\
\hline 51. & Bonkalmishak* & Iротоеа тахіта & Convolvulaceae & Climber & Leaf & abundant & Riverside & Perennial \\
\hline 52. & Lettuch & Lactuca sativa & Asteraceae & Herb & Leaf & Common & Fallow land & Annual \\
\hline 53. & Kata kachu & Lasia spinosa & Araceae & Herb & Rhizome, Petiole & Rare & Bush & Perennial \\
\hline 54. & Dondokalas & Leucas aspera & Lamiaceae & Herb & Leaf & Rare & Fallow land & Annual \\
\hline 55. & Dondokoas (boro) & Leucas cephalotes & Lamiaceae & Herb & Leaf & Rare & Crop field & Annual \\
\hline 56. & Kesordam & Ludwigia adscendens & Onagraceae & Herb & Leaf & abundant & Riverside & Perennial \\
\hline 57. & Kasava & Manihot esculenta & Euphorbiaceae & Shrub & Root & Common & Bush & Perennial \\
\hline 58. & Susnishak & Marsilea minuta & Marsileaceae & Herb & Leaf & abundant & Riverside & Annual \\
\hline 59. & Susnishak & Marsilea quadrifolia & Marsileaceae & Herb & Leaf & abundant & Riverside & Annual \\
\hline 60. & Pudina & Mentha sicata & Lamiaceae & Herb & Leaf & Common & Fallow land & Annual \\
\hline 61. & Dhekiashak* & Microlepia strigosoa & Dennstaedtiaceae & Herb & Leaf & abundant & Riverside & Perennial \\
\hline 62. & Refugeelata & Mikania cordata & Asteraceae & Climber & Leaf & abundant & Roadside & Perennial \\
\hline 63. & Sondha shak* & Mirabilis jalapa & Nyctaginaceae & Herb & Leaf & Common & Fallow land & Annual \\
\hline 64. & Titakoralashak* & Momordica charantia & Cucurbitaceae & Climber & Fruit, Leaf & Common & Roadside & Annual \\
\hline 65. & Bonkakrol & Momordica cochinchinensis & Cucurbitaceae & Climber & Leaf, Fruit & Rare & Bush & Annual \\
\hline 66. & Boro nokha * & Monochoria hastata & Pontederiaceae & Herb & Leaf & Common & Riverside & Annual \\
\hline 67. & Padma & Nelumbo nucifera & Nelumbonaceae & Herb & Fruit & Common & Riverside & Annual \\
\hline 68. & Shapla (pink)* & Nymphaea capensis & Nymphaeaceae & Herb & Petiole & Common & Riverside & Perennial \\
\hline 69. & Shapla (sada) & Nymphaea nouchali & Nymphaeaceae & Herb & Petiole & Common & Riverside & Perennial \\
\hline 70. & Shaluk & Nymphaea pubescens & Nymphaeaceae & Herb & Fruit & Common & Riverside & Annual \\
\hline 71. & Shapla (Red) & Nymphaea rubra & Nymphaeaceae & Herb & Petiole & Common & Riverside & Perennial \\
\hline & Tulsi & Ocimum americanum & Lamiaceae & Herb & Leaf & abundant & Riverside & Annual \\
\hline 73. & Dudkalmi $*$ & Operculina turpethum & Convolvulaceae & Climber & Leaf & abundant & Fallow land & Perennial \\
\hline 74. & Panikola * & Ottelia alismoides & Hydrocharitaceae & Herb & Fruit & Common & Riverside & Annual \\
\hline 75. & Aamrul & Oxalis corniculata & Oxalidaceae & Herb & Leaf & abundant & Riverside & Annual \\
\hline 76. & Gandhashak & Paederia foedtida & Rubiaceae & Herb & Leaf & Common & Bush & Perennial \\
\hline 77. & Luchi shak * & Peperomia pellucida & Piperaceae & Herb & Leaf & Common & Fallow land & Annual \\
\hline 78. & Vuiamla & Phyllanthus niruri & Phyllanthaceae & Herb & Leaf & abundant & Fallow land & Annual \\
\hline 79. & Potka & Physalis angulata & Solanaceae & Herb & Leaf, Fruit & abundant & Fallow land & Annual \\
\hline 80. & Luniashak & Portulaca oleracea & Portulaceae & Herb & Leaf & Rare & Fallow land & Annual \\
\hline 81. & Shamtorkari* & Psophocarpus tetragonolobus & Fabaceae & Climber & Fruit & Common & Bush & Annual \\
\hline 82. & Dhekiashak* & Pteris cretica & Pteridaceae & Herb & Leaf & abundant & Bush & Perennial \\
\hline 83. & Veron & Ricinus communis & Euphorbiaceae & Shrub & Seed kernel & Rare & Riverside & Annual \\
\hline 84. & Bon palong & Rumex dentatus & Polygonaceae & Herb & Leaf & Common & Fallow land & Perennial \\
\hline
\end{tabular}




\begin{tabular}{|c|c|c|c|c|c|c|c|c|}
\hline & Local name & Scientific name & Family & Habit & Parts used & Availability & Habitat & Life form \\
\hline 85. & Bondhone & Scoparia dulcis & Scrophulariaceae & Herb & Leaf & abundant & Fallow land & Annual \\
\hline 86. & Nuntashak * & Sesuvium portulacastrum & Aizoaceae & Herb & Leaf & Rare & Fallow land & Perennial \\
\hline 87. & Titbegun $*$ & Solanum indicum & Solanaceae & Herb & Leaf & abundant & Bush & Annual \\
\hline 88 . & Makai & Solanum nigram & Solanaceae & Herb & Leaf & abundant & Fallow land & Annual \\
\hline 89. & Nakfulshak* & Spilanthes calva & Asteraceae & Climber & Leaf & abundant & Fallow land & Annual \\
\hline 90 . & Gulonchoshak & Tinospora cordifolia & Menispermaceae & Climber & Leaf & Common & Bush & Perennial \\
\hline 91. & Randhuni & Trachyspermum roxburghiana & Apiaceae & Herb & Leaf & abundant & Bush & Annual \\
\hline 92. & Paniphal & Trapa natans & Lythraceae & Herb & Fruit & Common & Riverside & Annual \\
\hline 93. & Hogla & Typha angustata & Typhaceae & Herb & Seed & Common & Riverside & Perennial \\
\hline & Ghetkachu & Typhonium trilobatum & Araceae & Herb & Aerial portion & abundant & Roadside & Annual \\
\hline & Ghagra & Xanthomonas strumarium & Asteraceae & Herb & Leaf & Common & Roadside & Annual \\
\hline 96. & Malbikachu * & Xanthosoma atrovirens & Araceae & Herb & Petiole, Rhizome & abundant & Bush & Perennial \\
\hline 97. & Mukhikachu * & Xanthosoma sagittifolium & Araceae & Herb & Petiole, Stolon & Common & Fallow land & Perennial \\
\hline 98. & Dudkachu & Xanthosoma violaceum & Araceae & Herb & Rhizome & Common & Fallow land & Perennial \\
\hline 99. & Kalakachu * & Xanthosoma violaceum & Araceae & Herb & Stolon, Leaf, Petiole & Common & Riverside & Perennial \\
\hline 100 & Rakhalsosa & Zehneria scabra & Cucurbitaceae & Climber & Fruit & abundant & Bush & Annual \\
\hline
\end{tabular}

Table 3. Comparative study of wild vegetable with respect family, genus and species.

\begin{tabular}{|c|c|c|c|c|c|}
\hline Name of plant family & No. of floral genera & No. of floral species & Name of plant family & No. of floral genera & No. of floral species \\
\hline Araceae & 6 & 10 & Angiopteridacea & 1 & 1 \\
\hline Asteraceae & 6 & 6 & Liliaceae & 1 & 1 \\
\hline Amaranthaceae & 5 & 11 & Acoraceae & 1 & 1 \\
\hline Euphorbiaceae & 4 & 5 & Caesalpiniaceae & 1 & 1 \\
\hline Apiaceae & 4 & 4 & Commelinaceae & 1 & 1 \\
\hline Lamiaceae & 3 & 4 & Vitaceae & 1 & 1 \\
\hline Cucurbitaceae & 3 & 4 & Parkeriaceae & 1 & 1 \\
\hline Fabaceae & 3 & 3 & Moraceae & 1 & 1 \\
\hline Nymphaeaceae & 2 & 5 & Blechnaceae & 1 & 1 \\
\hline Convolvulaceae & 2 & 4 & Chenopodiaceae & 1 & 1 \\
\hline Solanaceae & 2 & 3 & Onagraceae & 1 & 1 \\
\hline Nyctaginaceae & 2 & 2 & Pteridaceae & 1 & 1 \\
\hline Dioscoriaceae & 1 & 3 & Tiliaceae & 1 & 1 \\
\hline Athyriaceae & 1 & 2 & Dennstaedtiaceae & 1 & 1 \\
\hline Marsileaceae & 1 & 2 & Hydrocharitaceae & 1 & 1 \\
\hline Scrophulariaceae & 1 & 2 & Rubiaceae & 1 & 1 \\
\hline Portulaceae & 1 & 1 & Oxalidaceae & 1 & 1 \\
\hline Lythraceae & 1 & 1 & Poaceae & 1 & 1 \\
\hline Aizoaceae & 1 & 1 & Typhaceae & 1 & 1 \\
\hline Pontederiaceae & 1 & 1 & Piperaceae & 1 & 1 \\
\hline Nelumbonaceae & 1 & 1 & Menispermaceae & 1 & 1 \\
\hline Malvaceae & 1 & 1 & Sapindaceae & 1 & 1 \\
\hline Phyllanthaceae & 1 & 1 & Polygonaceae & 1 & 1 \\
\hline
\end{tabular}


Table 4. Diversity among evaluation criteria.

\begin{tabular}{|c|c|c|c|c|}
\hline Serial no & $\begin{array}{l}\text { Evaluation } \\
\text { parameter }\end{array}$ & Sub- criteria & $\begin{array}{l}\text { Assignment score } \\
(\%)\end{array}$ & $\begin{array}{l}\text { Correlation with } \\
\text { market potentiality }\end{array}$ \\
\hline \multirow[t]{4}{*}{1.} & Taste & Most preferred & $54 \%$ & High \\
\hline & & Commonly preferred & $22 \%$ & High \\
\hline & & Preferred but not common & $13 \%$ & General \\
\hline & & Occasionally used & $11 \%$ & Low \\
\hline \multirow[t]{2}{*}{2.} & Ethnomedicinal value & Known & $65 \%$ & High \\
\hline & & Unknown & $35 \%$ & Low \\
\hline \multirow[t]{4}{*}{3.} & Use frequency & Widely used & $51 \%$ & High \\
\hline & & Commonly used & $21 \%$ & General \\
\hline & & Occasionally used & $16 \%$ & General \\
\hline & & Rare used & $12 \%$ & Low \\
\hline \multirow[t]{3}{*}{4.} & Distribution area & Most region & $43 \%$ & General \\
\hline & & Certain region & $24 \%$ & High \\
\hline & & Remote region & $29 \%$ & High \\
\hline \multirow[t]{3}{*}{5.} & Community status & Abundant & $33 \%$ & General \\
\hline & & Common & $25 \%$ & General \\
\hline & & Rare & $42 \%$ & High \\
\hline
\end{tabular}

\section{Conclusions}

This is the first market survey on wild vegetables consumed by the local people of Barisal district. The findings is consistent with other authors findings with regard to parts used, ethnomedicinal value, gender involvement, plant habits and habitats, but partially consistent with regard to name of mostly contributed family, seasonal availability. The study revealed that the local inhabitants of this district has wide knowledge on consumption of wild vegetables. As a result local people of this district consume a plenty of wild vegetables and amazing news is that surplus wild vegetables are also being marketed in metropolitan city markets. Another surprising news is that some family totally depend upon vegetables available around their homestead flora and maximum portion of these vegetables are wild. Documentation and preservation of wild vegetables knowledge is not only indispensable for the communities, but also valuable for scientific studies for sustainable uses. Further agronomical investigations on these wild vegetables is greatly needed in this regard. Our findings could provide baseline data to explore alternative vegetables from this district by agriculturists to meet up increasing demand of future generation and attention to conservation policy maker to manage these natural resources from overexploitation and degradation.

\section{Acknowledgements}

The author acknowledged the University of Barisal authority for management support for this study. The author also grateful to local wild vegetable sellers (informants) of Barisal district for contribution in the data collection process.

\section{Conflict of interest}

None to declare.

\section{References}

Abdullah MR, MJ Uddin, S Sultana and MH Rashid, 2007. Biodiversity of leafy vegetables in two villages of sadar upazilla of Mymensingh district. J. Bangladesh Soc. Agric. Sci. Technol., 4: 131-134.

Abdullah MR, ME Haque, MM Rahman and MSA Fakir, 2017. Diversity of Traditional Leafy Vegetables in Two Villages of 'Kaptai' Reserve Forest, 'Rangamati', Bangladesh. Journal of Agroecology and Natural Resource Management, 4: 203-207.

Ahmed ZU, ZNT Begum, MA Hassan, M Khondker, SMH Kabir, M Ahmad, ATA Ahmed, AKA Rahman and EU Haque, 2007-2009. Encyclopedia of Flora and Fauna of Bangladesh, Vols. 7-12. Asiatic Society of Bangladesh, Dhaka.

Alexiades MN, 1996. Selected Guidelines for Ethnobotanical Research: A Field Manual, The New York Botanical Garden, New York. pp. 305.

Baro D, S Baruah and SK Borthukar, 2015. Documentation on wild vegetables of Basaka district, BTAD (Assam). Archives of Applied Science Research, 7: 19-27.

Bista DB, 2004. People of Nepal. Ratna Pustak Bhandar, Kathamandu. 
Brand-Miller JC and HA Holt, 1998. Australian aboriginal plant foods: a consideration of their nutritional composition and health implication. Nutr. Res Rev., 11: 5-23.

Cook JA, DJ Vanderjagt, A Pastuszyn, G Mounkaila, RS Glew, M Millson and RH Glew, 2000. Nutrient and chemical composition of 13 wild plant foods of Niger. J. Food Compos. Anal., 13: 83-92.

FAO, 1984. In situ conservation of wild plant genetic resources: A status review and action plant document by FAO and IUCN, Rome. pp. 83.

FAO, 1997. Land resources appraisal of Bangladesh for agricultural development, report 2: Agro-ecological regions of Bangladesh, UNDP, FAO, pp. 570.

Freiberger CE, DJ Vanderjagt, A Pastuszyn, RS Glew, G Mounkaila, M Millson and RH Glew, 1998. Nutrient content of the edible leaves of seven wild plants from Niger. Plant Foods Hum. Nutr., 53: 57-69.

Grivetti LE and BM Ogle, 2000. Value of traditional foods in meeting macro- and micronutrient needs: the wild plant connection. Nutr. Res Rev., 13: 31-46.

Hyland BPM, 1972. A technique for collecting botanical specimens in rain forest, Flora Malesiana Bull., 26: 2038-2040.

Khatun M, MA Hassan, SN Islam and MO Rahman, 2013. Taxonomy of the Leafy Vegetables of Bangladesh. Bangl. J. Plant Taxon., 20: 95-123.

Ladio AH and M Lozada, 2004. Patterns of use and knowledge of wild edible plants in distinct ecological environments: A case study of a Mapuche community from northwestern Patagonia. Biodiversity and Conservation, 13: 1153-1173.

Mojumdar P and AHMM Rahman, 2018. Investigation on wild and cultivated leafy vegetables in Rajshahi district of Bangladesh. Indian J. Sci., 25: 20-34.

Phillips O and AH Gentry, 1993. The useful plants of Tamboapata, Peru: II additional hypothesis testing in quantitative ethnobotany. Econ. Bot., 47: 33-43.

Rahman AHMM, S Akter, R Rani, and AKMR Islam, 2015. Taxonomic Study of Leafy Vegetables at Santahar Pouroshova of District Bogra, Bangladesh with Emphasis on Medicinal Plants. Int. J. Adv. Res., 3: 10191036.

Rashid MM, 1996. Vegetables Crops Agribusiness-A Consultancy Report. Bangladesh- AVRDC Vegetables Research Project, BARI, pp. 253.

RASHID MM, 1999. Sabji Bigghan (In Bangla), Rashid Publishing House, Dhaka-1206.

Sajib NH and SB Uddin, 2012. Diversity of wild vegetables of Sandwip Island in Chittagong, Bangladesh. The Chittagong Univ. J. B. Sci., 7: 11-20.

Sarker SK, and ABME Hossain, 2009. Pteridophytes of greater Mymensingh district of Bangladesh used as vegetables and medicines, Bangladesh J. Plant Taxon., 16: 47-56. 